Supporting Information:

\title{
Economic Dependence of U.S. Industrial Sectors on Animal-mediated Pollination Service
}

\author{
Shauhrat S. Chopra ${ }^{1}$, Bhavik R. Bakshi ${ }^{2}$ and Vikas Khanna* ${ }^{1}$ \\ ${ }^{1}$ Department of Civil and Environmental Engineering, University of Pittsburgh, \\ Pittsburgh, PA 15261 \\ ${ }^{2}$ William G. Lowrie Department of Chemical and Biomolecular Engineering, The Ohio \\ State University, Columbus, OH, 43210 \\ *Corresponding Author's address: Swanson School of Engineering, Department of Civil \\ and Environmental Engineering, University of Pittsburgh, 218G Benedum Hall, 3700 \\ O'Hara Street, Pittsburgh, PA 15261; tel: +1-412-624-9603; fax: +1-412-624-0135; \\ email:khannav@pitt.edu
}

Number of pages: 12

Number of figures: 2

Number of tables: 4 


\section{Methodological Framework for Assessing Economic Dependence}

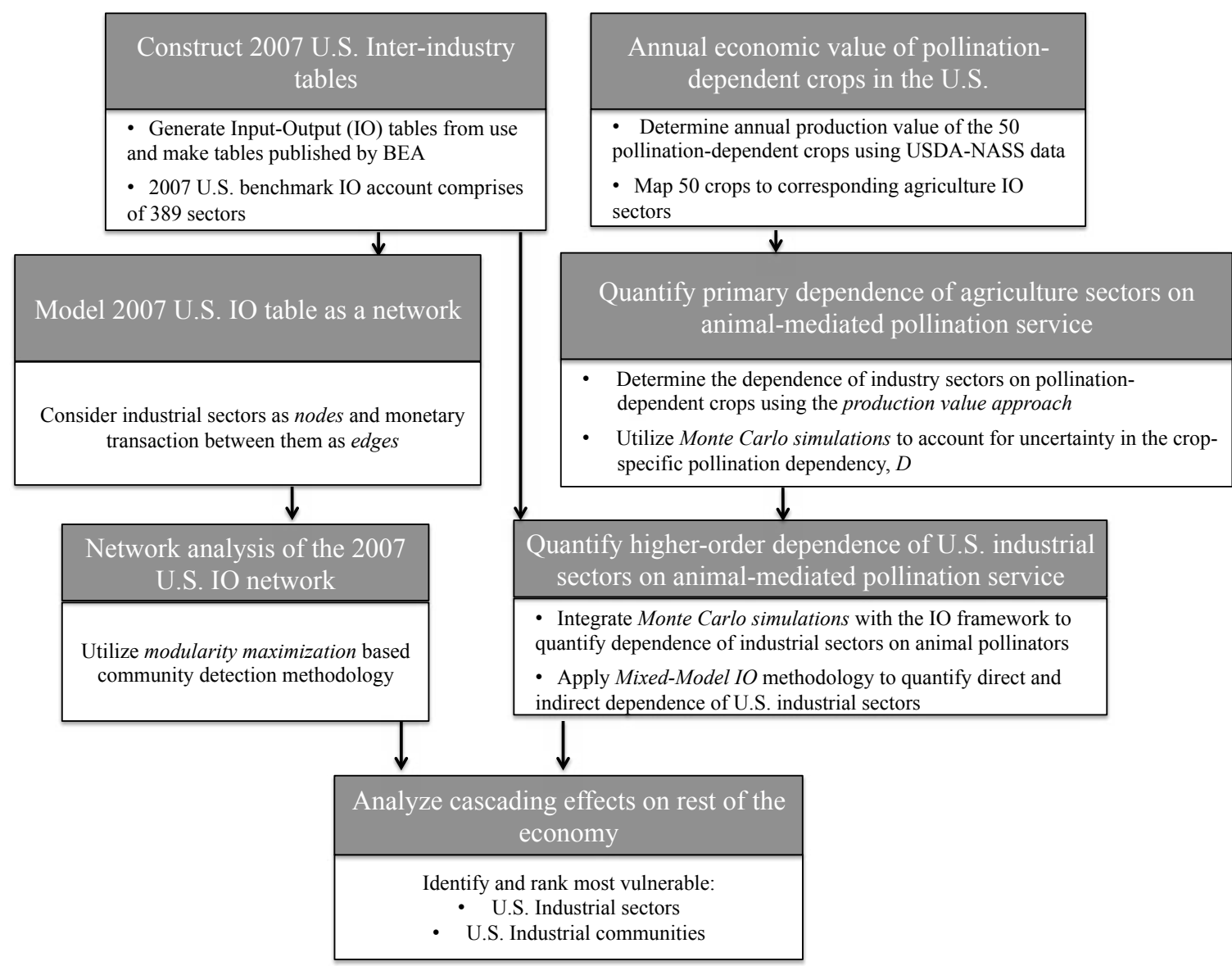

Figure S1. Methodological framework for assessing economic dependence of the U.S. industrial sectors on animal-mediated pollination service 


\section{Primary Economic Dependence of Agriculture Sectors on Animal-mediated Pollination Service}

Table S1. Pollinator Dependence $D_{i}$ range for individual crops in the U.S. based on data reported by Klein et al. ${ }^{1}$

\begin{tabular}{|c|c|c|c|c|c|}
\hline $\begin{array}{c}\text { Pollinator } \\
\text { Dependent } \\
\text { Crops in the } \\
\text { U.S. }\end{array}$ & $\begin{array}{l}\text { Corresponding IO } \\
\text { agriculture sectors }\end{array}$ & $\begin{array}{l}\mathrm{V}=2007 \text { Value } \\
\text { in US \$ millions }\end{array}$ & $\begin{array}{l}\text { Impact of } \\
\text { animal } \\
\text { pollination } 1\end{array}$ & $\begin{array}{l}\text { Lower bound } \\
\text { of Pollination } \\
\text { dependency } D^{1}\end{array}$ & $\begin{array}{l}\text { Upper bound } \\
\text { of Pollination } \\
\text { dependency } D^{1}\end{array}$ \\
\hline Almond & $\begin{array}{l}\text { Fruit and tree nut } \\
\text { farming }\end{array}$ & 2401.8 & Great & 0.4 & 0.9 \\
\hline Apple & $\begin{array}{l}\text { Fruit and tree nut } \\
\text { farming }\end{array}$ & 2608.2 & Great & 0.4 & 0.9 \\
\hline Apricot & $\begin{array}{l}\text { Fruit and tree nut } \\
\text { farming }\end{array}$ & 42.2 & Great & 0.4 & 0.9 \\
\hline Avocado & $\begin{array}{l}\text { Fruit and tree nut } \\
\text { farming }\end{array}$ & 328.1 & Great & 0.4 & 0.9 \\
\hline Blueberry & $\begin{array}{l}\text { Fruit and tree nut } \\
\text { farming }\end{array}$ & 614.1 & Great & 0.4 & 0.9 \\
\hline Raspberries & $\begin{array}{l}\text { Fruit and tree nut } \\
\text { farming }\end{array}$ & 262.7 & Great & 0.4 & 0.9 \\
\hline Blackberries & $\begin{array}{l}\text { Fruit and tree nut } \\
\text { farming }\end{array}$ & 28.6 & Great & 0.4 & 0.9 \\
\hline Boysenberry & $\begin{array}{l}\text { Fruit and tree nut } \\
\text { farming }\end{array}$ & 3.1 & Great & 0.4 & 0.9 \\
\hline Sweet cherry & $\begin{array}{l}\text { Fruit and tree nut } \\
\text { farming }\end{array}$ & 557.1 & Great & 0.4 & 0.9 \\
\hline Tart cherry & $\begin{array}{l}\text { Fruit and tree nut } \\
\text { farming }\end{array}$ & 67.9 & Great & 0.4 & 0.9 \\
\hline Grapefruit & $\begin{array}{l}\text { Fruit and tree nut } \\
\text { farming }\end{array}$ & 311.9 & Little & 0 & 0.1 \\
\hline Lemon & $\begin{array}{l}\text { Fruit and tree nut } \\
\text { farming }\end{array}$ & 449.4 & Little & 0 & 0.1 \\
\hline Orange & $\begin{array}{l}\text { Fruit and tree nut } \\
\text { farming }\end{array}$ & 2216.5 & Little & 0 & 0.1 \\
\hline Tangelo & $\begin{array}{l}\text { Fruit and tree nut } \\
\text { farming }\end{array}$ & 13.7 & Little & 0 & 0.1 \\
\hline Tangerine & $\begin{array}{l}\text { Fruit and tree nut } \\
\text { farming }\end{array}$ & 156.2 & Little & 0 & 0.1 \\
\hline Cranberry & $\begin{array}{l}\text { Fruit and tree nut } \\
\text { farming }\end{array}$ & 332.1 & Great & 0.4 & 0.9 \\
\hline Kiwifruit & $\begin{array}{l}\text { Fruit and tree nut } \\
\text { farming }\end{array}$ & 22.5 & Essential & 0.9 & 1 \\
\hline Macadamia & $\begin{array}{l}\text { Fruit and tree nut } \\
\text { farming }\end{array}$ & 24.6 & Essential & 0.9 & 1 \\
\hline
\end{tabular}




\begin{tabular}{|c|c|c|c|c|c|}
\hline Nectarine & $\begin{array}{l}\text { Fruit and tree nut } \\
\text { farming }\end{array}$ & 96.3 & Great & 0.4 & 0.9 \\
\hline Peach & $\begin{array}{l}\text { Fruit and tree nut } \\
\text { farming }\end{array}$ & 502.1 & Great & 0.4 & 0.9 \\
\hline Pear & $\begin{array}{l}\text { Fruit and tree nut } \\
\text { farming }\end{array}$ & 363.1 & Great & 0.4 & 0.9 \\
\hline Plum/prune & $\begin{array}{l}\text { Fruit and tree nut } \\
\text { farming }\end{array}$ & 223.5 & Great & 0.4 & 0.9 \\
\hline Strawberry & $\begin{array}{l}\text { Fruit and tree nut } \\
\text { farming }\end{array}$ & 1751.1 & Modest & 0.1 & 0.4 \\
\hline Fig & $\begin{array}{l}\text { Fruit and tree nut } \\
\text { farming }\end{array}$ & 37.3 & Modest & 0.1 & 0.4 \\
\hline Papaya & $\begin{array}{l}\text { Fruit and tree nut } \\
\text { farming }\end{array}$ & 13.1 & Little & 0 & 0.1 \\
\hline Coffee & $\begin{array}{l}\text { Fruit and tree nut } \\
\text { farming }\end{array}$ & 31.9 & Modest & 0.1 & 0.4 \\
\hline Asparagus $^{\#}$ & $\begin{array}{l}\text { Vegetable and melon } \\
\text { farming }\end{array}$ & 104.1 & Essential & 0.9 & 1 \\
\hline Broccoli $^{\#}$ & $\begin{array}{l}\text { Vegetable and melon } \\
\text { farming }\end{array}$ & 694.9 & Essential & 0.9 & 1 \\
\hline Carrot $^{\#}$ & $\begin{array}{l}\text { Vegetable and melon } \\
\text { farming }\end{array}$ & 567.6 & Essential & 0.9 & 1 \\
\hline Cauliflower $^{\#}$ & $\begin{array}{l}\text { Vegetable and melon } \\
\text { farming }\end{array}$ & 233.4 & Essential & 0.9 & 1 \\
\hline Celery $^{\#}$ & $\begin{array}{l}\text { Vegetable and melon } \\
\text { farming }\end{array}$ & 408.0 & Essential & 0.9 & 1 \\
\hline $\begin{array}{c}\text { Fresh } \\
\text { cucumber }\end{array}$ & $\begin{array}{l}\text { Vegetable and melon } \\
\text { farming }\end{array}$ & 238.9 & Great & 0.4 & 0.9 \\
\hline $\begin{array}{l}\text { Pickled } \\
\text { cucumber }\end{array}$ & $\begin{array}{l}\text { Vegetable and melon } \\
\text { farming }\end{array}$ & 175.8 & Great & 0.4 & 0.9 \\
\hline Cantaloupe & $\begin{array}{l}\text { Vegetable and melon } \\
\text { farming }\end{array}$ & 302.5 & Essential & 0.9 & 1 \\
\hline Honeydew & $\begin{array}{l}\text { Vegetable and melon } \\
\text { farming }\end{array}$ & 73.5 & Essential & 0.9 & 1 \\
\hline Onion $^{\#}$ & $\begin{array}{l}\text { Vegetable and melon } \\
\text { farming }\end{array}$ & 817.0 & Essential & 0.9 & 1 \\
\hline Pumpkin & $\begin{array}{l}\text { Vegetable and melon } \\
\text { farming }\end{array}$ & 123.5 & Essential & 0.9 & 1 \\
\hline Squash & $\begin{array}{l}\text { Vegetable and melon } \\
\text { farming }\end{array}$ & 163.1 & Essential & 0.9 & 1 \\
\hline Tomato & $\begin{array}{l}\text { Vegetable and melon } \\
\text { farming }\end{array}$ & 2070.4 & Little & 0 & 0.1 \\
\hline Watermelon & $\begin{array}{l}\text { Vegetable and melon } \\
\text { farming }\end{array}$ & 422.5 & Essential & 0.9 & 1 \\
\hline Lint cotton & Other crop farming & 5652.9 & Modest & 0.1 & 0.4 \\
\hline
\end{tabular}




\begin{tabular}{|c|c|c|c|c|c|}
\hline Seed cotton & Other crop farming & 1069.8 & Modest & 0.1 & 0.4 \\
\hline Peanut & Other crop farming & 758.6 & Little & 0 & 0.1 \\
\hline Rapeseed & Oilseed farming & 0.2 & Modest & 0.1 & 0.4 \\
\hline Soybean & Oilseed farming & 26974.4 & Modest & 0.1 & 0.4 \\
\hline Sunflower & Oilseed farming & 614.7 & Modest & 0.1 & 0.4 \\
\hline $\begin{array}{c}\text { Mustard } \\
\text { Seeds }\end{array}$ & Oilseed farming & 9.7 & Modest & 0.1 & 0.4 \\
\hline Safflower & Oilseed farming & 39.1 & Little & 0 & 0.1 \\
\hline Flaxseed & Oilseed farming & 76.5 & Little & 0 & 0.1 \\
\hline Canola & Oilseed farming & 260.3 & Great & 0.4 & 0.9 \\
\hline & $\begin{array}{l}\text { \# Data unavailable for these crops from Klein at al. }{ }^{1} \text { Data from Morse and Calderone used to assign } \\
\text { these crops to different categories. }{ }^{3}\end{array}$ \\
\hline
\end{tabular}


Table S2. Primary economic dependence of agriculture sectors on animal-mediated pollination service. Annual total throughput represents the value of production for crops irrespective of their dependence on pollination service.

\begin{tabular}{|l|r|lr|}
\hline & $\begin{array}{l}\text { Annual Total } \\
\text { Throughput of U.S. IO } \\
\text { IO- Agriculture Sector }\end{array}$ & $\begin{array}{l}\text { Crop Production } \\
\text { Dependent on Pollinators } \\
\text { (US\$ millions) }\end{array}$ \\
\hline Oilseed farming & 21425 & 7088 \\
\hline Vegetable and melon farming & 18718 & 4087 \\
\hline Fruit and tree nut farming & 18867 & 6134 \\
\hline Other crop farming & 20636 & 1711 \\
\hline
\end{tabular}




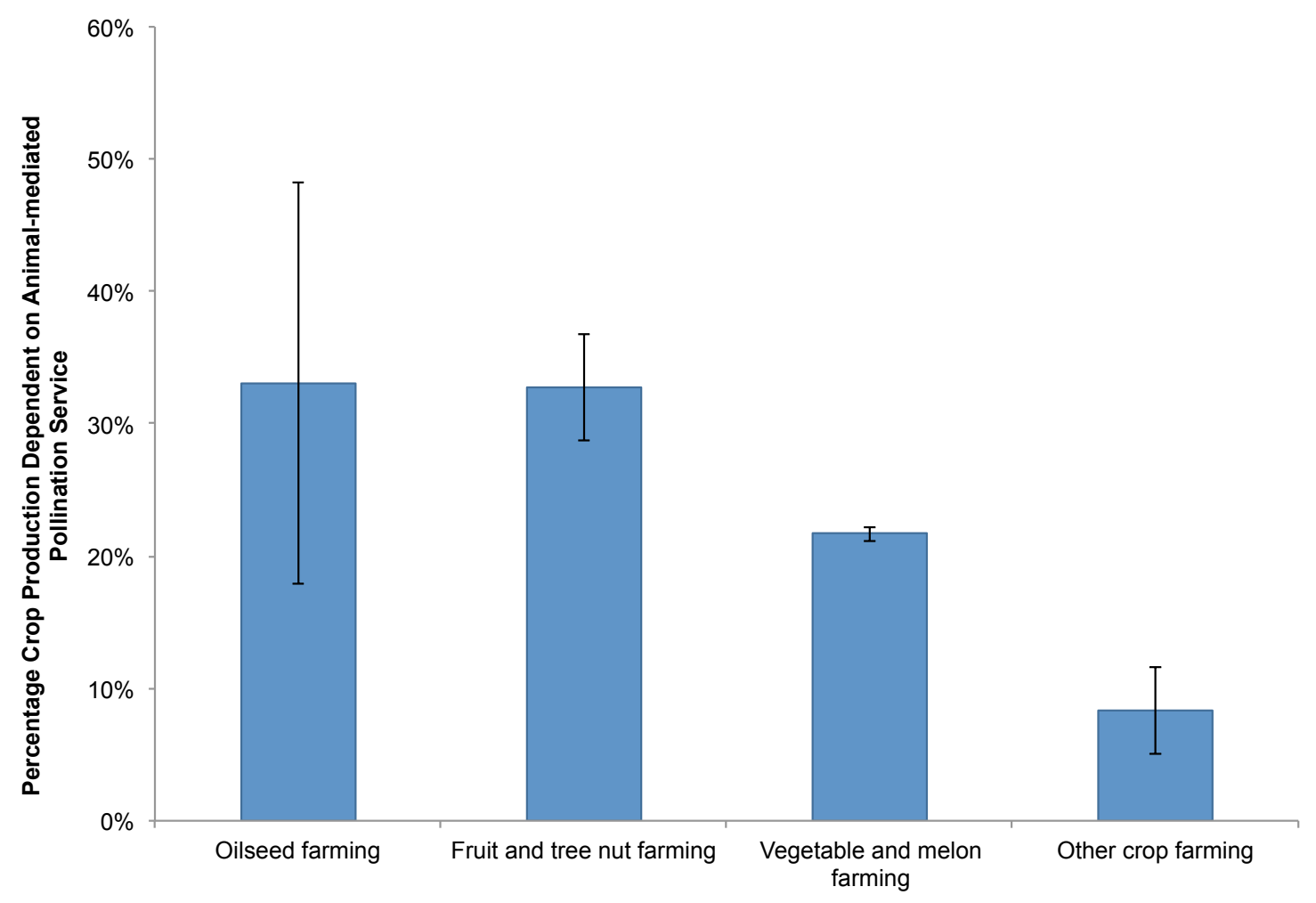

Figure S2. Primary economic dependence of each agriculture IO sector in terms of the percentage of annual crop production dependent on pollination service. The solid bars represent the mean $\%$ of crop production dependent on pollination service, while the error bars represent the $10^{\text {th }}$ and $90^{\text {th }}$ percentiles. 


\section{Input-Output Model: Demand and Supply-side IO methods}

Demand-side model is useful for determining the impact of a perturbation that causes a reduction in demand from a particular sector. Changing government spending and consumer apprehension are examples of perturbations that may reduce final demand. ${ }^{4}$ For example, an outbreak of E.coli strain that causes a decrease in the total final demand from the fruit and vegetable industry. For a changed final demand $F_{n e w}$, the direct economic activity is $A x F_{n e w}$, while the total economic activity is calculated by $X=(I-A)^{-1} F_{\text {new }}$

The term $(I-A)^{-1}$ is called the Leontief inverse and back tracks the supply side information. The changed final demand term is an exogenous variable and will drive the demand-side model once it is specified. The above-mentioned equation is the demand driven model.

Supply-side model is useful for determining the impact of a value-added perturbation on an industry, for example a labor strike or an import embargo. ${ }^{4}$ While the demand-side model is only applicable for analyzing IO tables that capture inter-industry transactions in terms of their monetary value, the supply-side model is able to take into account the impact of price changes in the value-added as well. Certain industrial disruptions may not result in production quantities due to the immediate managerial action that might cause an increase in the cost of production. For example, the higher wages paid by hospitals to compensate its staff for longer working hours during an outbreak is the value-added price perturbation vector. One may observe that increasing value-added price (an exogenous variable) of a particular sector cascades to other industries and changes their total output. Thus we can derive the changed total economic activity for a new value added $V_{\text {new }}$ from the supply-driven model equation:

$$
X=\left(I-B^{T}\right)^{-1} V_{\text {new }}
$$

where $\left(I-B^{T}\right)^{-1}$ is called the Ghosh inverse. Transaction coefficients for the Ghosh matrix is defined as $b_{i j}=z_{i j} / x_{i}$. Thus, these demand and supply driven models are useful in modeling shocks that affect either the final demand $F$ or the value-added $V$ of an industry, and determine their impacts on other industries in the economy.

In the two models described above, either final demand or value-added are considered exogenous and the total sector output is considered endogenous, thus based on the changed exogenous variables, the endogenous variables are computed. Neither of the two approaches are valuable for studying the impact of supply shortage, facility closure, or supply-chain disruption. For this reason, mixed-model IO methodology is applied to 
assess the impact of reduction in annual economic throughput of the four agriculture sectors due to the degradation of animal-mediated pollination service.

\section{Mathematical description of the Mixed-model Input-Output methodology}

As mentioned in the paper, the mixed-model is a modification to the demand-driven model (equation 1) where final demand for non-supply constrained sectors is exogenously specified, and total throughput for supply-constrained sectors is endogenously specified. ${ }^{4}$ Using linear algebra for partitioned matrices, equation 3 is obtained. There are $n$ sectors in the economy, out of which the first $k$ sectors have final demand as the exogenous elements, and the last $(n-k)$ sectors are those for which the total throughput are the exogenous elements.

$$
\left[\begin{array}{cc}
P & 0 \\
R & -I
\end{array}\right]\left[\begin{array}{l}
X \\
F
\end{array}\right]=\left[\begin{array}{ll}
I & Q \\
0 & S
\end{array}\right]\left[\begin{array}{c}
\bar{F} \\
\bar{X}
\end{array}\right]
$$

$\bar{F}$ is the $k$-element column vector of elements $F_{l}$ through $F_{k}$, representing exogenous final demands of non-supply constrained sectors (known).

$\bar{X}$ is the $(n-k)$ element column vector of elements $X_{k-1}$ through $X_{n}$, representing exogenous total outputs of the supply constrained sectors (agricultural sectors).

$X$ is the $k$-element column vector of elements $X_{1}$ through $X_{k}$, the total output of nonsupply constrained sectors (to be estimated).

$F$ is the $(n-k)$ element column vector of elements $F_{k-1}$ through $F_{n}$, the final demand of supply-constrained sectors (to be estimated).

$P$ is the $k \times k$ matrix containing the elements from the first $k$ rows and the first $k$ columns in $(I-A)$.

$R$ is the $(n-k) \times k$ matrix containing elements from the last $(n-k)$ rows and the first $k$ columns in $(I-A)$.

$Q$ is the $k \times(n-k)$ matrix of elements from the first $k$ rows and the last $(n-k)$ columns in $-(I-A)$.

$S$ is the $(n-k) \times(n-k)$ matrix of elements from the last $(n-k)$ rows and columns of $-(I-A)$.

We can rearrange equation 2 as:

$$
M\left[\begin{array}{l}
X \\
F
\end{array}\right]=N\left[\begin{array}{l}
\bar{F} \\
\bar{X}
\end{array}\right]
$$

where

$$
M=\left[\begin{array}{cc}
P & 0 \\
R & -I
\end{array}\right]
$$

and 


$$
N=\left[\begin{array}{ll}
I & Q \\
0 & S
\end{array}\right]
$$

The total throughput for the first $k$, non-supply constrained sectors and the final demand for the last $n-k$, supply-constrained sectors is determined using equation 7 .

$$
\left[\begin{array}{l}
X \\
F
\end{array}\right]=M^{-1} N\left[\begin{array}{l}
\bar{F} \\
\bar{X}
\end{array}\right]
$$

Table S3. Final demand of supply-constrained sectors before and after change in their output. Output change of supply-constrained sectors results in a decrease in their final demand, with the understanding that imports increase and exports decrease. Negative final demand reflects that the demand exceeds the domestic production.

\begin{tabular}{|l|r|r|}
\hline IO- Agriculture Sector & \multicolumn{1}{|c|}{$\begin{array}{c}\text { Final demand before } \\
\text { reduction in supply of } \\
\text { pollination service (US\$ } \\
\text { millions) }\end{array}$} & $\begin{array}{c}\text { Endogenous final } \\
\text { demand after reduction } \\
\text { in supply of pollination } \\
\text { service (US\$ millions) }\end{array}$ \\
\hline Oilseed farming & 4921.5 & -720.0 \\
\hline $\begin{array}{l}\text { Vegetable and melon } \\
\text { farming }\end{array}$ & 13730.6 & 9625.2 \\
\hline & & 15.2 \\
\hline Fruit and tree nut farming & 7891.5 & 1408.4 \\
\hline
\end{tabular}




\section{Mathematical description of Network Clustering}

For determining industrial communities in our study we use the modularity based clustering approach for directed networks. Modularity, $Q$, for directed-weighted networks is defined as

$$
Q=\frac{1}{2 m} \sum_{i j}\left[Z_{i j}-\frac{s_{i}^{\text {in } s_{j}^{\text {out }}}}{2 m}\right] \delta_{c_{i}, c_{j}}=\frac{1}{2 m} \sum_{i j} B_{i j} \delta_{c_{i}},_{c_{j}}
$$

where,

$$
B_{i j}=Z_{i j}-\frac{S_{i} s_{j}}{2 m}
$$

and

$Z_{i j}$ is the value of monetary transaction from node $j$ to node $i$, and zero if there is no transaction in the inter-industry transaction matrix $(\mathrm{Z})$

$m$ is the number of transactions in the network

$s_{i}$ is the in-strength (magnitude of incoming transactions) for node $i$

$s_{j}$ is the out-strength (magnitude of outgoing transactions) for node $j$

$\delta_{i j}$ is the Kronecker delta symbol

$c_{i}$ is the community node $i$ is assigned

$c_{j}$ is the community node $j$ is assigned

We use the spectral optimization methodology to find the best division of the economic network by maximizing the value of $Q .{ }^{5}$ The modularity matrix, $B$, is an $n \times n$ matrix with elements $B_{i j}$. The algorithm for modularity maximization in simple terms assigns nodes to different communities based on the sign of the eigenvector, corresponding to the largest positive eigenvalue, of the modularity matrix. The above mentioned community detection algorithm of modularity maximization divides the network into exactly two communities. In order to identify the natural fault lines in the network by identifying natural groupings of nodes, we apply the repeated bisection graph-partitioning algorithm. This method basically starts by dividing the network in two and then repeating the divisions while keeping in mind the aim to maximize the modularity for the entire network. A good division of a network results in a high modularity score, thus we maximize $Q$ over all possible divisions of the economy to identify true industrial communities. ${ }^{5}$

Using this method, we identified 5 industrial communities form our economic network of 389 nodes. In the following table we provide information regarding the size (number of 
nodes) and economic dependence (sum of direct and indirect dependence of industries in the community) of industrial communities.

Table S4. Higher-order economic dependence of industrial communities on animalmediated pollination service. It is calculated by summing the annual economic dependence of industrial sectors that comprise each community.

\begin{tabular}{ccc}
\hline Industrial community & $\begin{array}{c}\text { Number of } \\
\text { industries }\end{array}$ & $\begin{array}{c}\text { Mean higher-order economic } \\
\text { dependence on animal pollinators } \\
\text { (US\$ millions) }\end{array}$ \\
\hline Service sectors & 74 & 1738.9 \\
Energy and Petroleum related sectors & 45 & 3802.3 \\
$\begin{array}{c}\text { Manufacturing and Resource } \\
\text { extraction sectors }\end{array}$ & 206 & 2862.3 \\
Financial and Healthcare sectors & 21 & 1160.2 \\
\hline $\begin{array}{c}\text { Agriculture and agriculture related } \\
\text { sectors }\end{array}$ & 43 & 2885.7 \\
\hline
\end{tabular}

\section{References}

1. Klein, A.-M.; Vaissière, B. E.; Cane, J. H.; Steffan-Dewenter, I.; Cunningham, S. A.; Kremen, C.; Tscharntke, T., Importance of pollinators in changing landscapes for world crops. Proceedings of the Royal Society B: Biological Sciences 2007, 274, (1608), 303-313.

2. Crop Values 2009 Summary. In USDA, Ed. National Agricultural Statistics Service: 2010.

3. Morse, R. A.; Calderone, N. W., The value of honey bees as pollinators of US crops in 2000. Bee Culture 2000, 128, (3), 1-15.

4. Miller, R. E.; Blair, P. D., Input-output analysis : foundations and extensions / Ronald E. Miller and Peter D. Blair. Cambridge University Press: Cambridge, UK; New York, 2009.

5. Leicht, E. A.; Newman, M. E. J., Community structure in directed networks. Physical Review Letters 2008, 100, (11), 118703. 